\title{
Article \\ One-Pot Synthesis of Nano CuO-ZnO Modified Hydrochar Derived from Chitosan and Starch for the $\mathrm{H}_{2} \mathrm{~S}$ Conversion
}

\author{
Lihua Zang ${ }^{1,2}$, Chengxuan Zhou ${ }^{2}$, Liming Dong ${ }^{1}$, Leilei Wang ${ }^{3}$, Jiaming Mao ${ }^{4}$, Xiaomin Lu ${ }^{5}$, Rong Xue ${ }^{2}$ \\ and Yunqian Ma $1,2, *$ (D)
}

1 Key Laboratory of Cleaner Production and Integrated Resource Utilization of China National Light Industry, Beijing Technology and Business University, Beijing 100048, China; zlh@qlu.edu.cn (L.Z.); donglm@btbu.edu.cn (L.D.)

2 College of Environmental Science and Engineering, Qilu University of Technology (Shandong Academy of Science), Jinan 250353, China; zhouchengxuan@ipe.ac.cn (C.Z.); xr@qlu.edu.cn (R.X.)

3 Ecology Institute of Shandong Academy of Sciences, Qilu University of Technology (Shandong Academy of Sciences), Jinan 250014, China; wangll@qlu.edu.cn

4 College of Environmental Science and Engineering, Beijing Forestry University, Beijing 100083, China; mjm2020@bjfu.edu.cn

5 Department of Forest Biomaterials, North Carolina State University, Raleigh, NC 27695, USA; xlu13@ncsu.edu

* Correspondence: mayq@qlu.edu.cn

Citation: Zang, L.; Zhou, C.; Dong, L.; Wang, L.; Mao, J.; Lu, X.; Xue, R.; $\mathrm{Ma}, \mathrm{Y}$. One-Pot Synthesis of Nano CuO-ZnO Modified Hydrochar Derived from Chitosan and Starch for the $\mathrm{H}_{2} \mathrm{~S}$ Conversion. Catalysts 2021, 11, 767. https://10.3390/ catal11070767

Academic Editor: Daniela Barba

Received: 18 May 2021

Accepted: 15 June 2021

Published: 24 June 2021

Publisher's Note: MDPI stays neutral with regard to jurisdictional claims in published maps and institutional affiliations.

Copyright: (c) 2021 by the authors. Licensee MDPI, Basel, Switzerland. This article is an open access article distributed under the terms and conditions of the Creative Commons Attribution (CC BY) license (https:/ / creativecommons.org/licenses/by/ $4.0 /)$.

\begin{abstract}
A novel kind of hydrochar adsorbent, modified by $\mathrm{CuO}-\mathrm{ZnO}$ and derived from chitosan or starch, was synthesized for $\mathrm{H}_{2} \mathrm{~S}$ adsorption. The prepared adsorbent was characterized by BET, XRD, EDX, SEM, and XPS. The results showed that the modified hydrochar contained many amino groups as functional groups, and the nanometer metal oxide particles had good dispersion on the surface of the hydrochar. The maximum sulfur capacity reached $28.06 \mathrm{mg} / \mathrm{g}$-adsorbent under the optimized conditions. The amine group significantly reduced the activation energy between $\mathrm{H}_{2} \mathrm{~S}$ and $\mathrm{CuO}-\mathrm{ZnO}$ conducive to the rapid diffusion of $\mathrm{H}_{2} \mathrm{~S}$ among the lattices. Simultaneously, cationic polyacrylamide as a steric stabilizer could change the formation process of $\mathrm{CuO}$ and $\mathrm{ZnO}$ nanoparticles, which made the particle size smaller, enabling them to react with $\mathrm{H}_{2} \mathrm{~S}$ sufficiently easily. This modified hydrochar derived from both chitosan and starch could be a promising adsorbent for $\mathrm{H}_{2} \mathrm{~S}$ removal.
\end{abstract}

Keywords: hydrochar; adsorbent; mixed metal oxides; $\mathrm{H}_{2} \mathrm{~S}$ conversion

\section{Introduction}

Hydrogen sulfide $\left(\mathrm{H}_{2} \mathrm{~S}\right)$, a poisonous, odorous, and corrosive gas, commonly exists in industrial gases such as coal gasification gas, natural gas, and biogas. $\mathrm{H}_{2} \mathrm{~S}$ is harmful to humans and livestock, and it not only brings corrosion to metal pipes and reaction devices in the industrial production process, but also causes catalyst poisoning, which affects product quality $[1,2] . \mathrm{H}_{2} \mathrm{~S}$ is easy to burn, generating $\mathrm{SO}_{2}$ as a combustion product. Whether through combustion or direct emissions, it can exert a severe impact on the atmospheric environment. Therefore, $\mathrm{H}_{2} \mathrm{~S}$ should be fixed on some materials or removed from the production process and environment.

At present, there are many industrial methods to remove $\mathrm{H}_{2} \mathrm{~S}$. According to production conditions and desulfurization costs, the methods of $\mathrm{H}_{2} \mathrm{~S}$ removal in industrial processes can be classified into wet flue gas desulfurization (WFGD) and dry flue gas desulfurization (DFGD) [3,4]. The desulfurizer of WFGD is a liquid that absorbs and separates $\mathrm{H}_{2} \mathrm{~S}$ with large processing capacity and mature technology. WFGD has some disadvantages - for example, high energy consumption, secondary pollution, and high regeneration cost. DFGD has mainly been used to remove $\mathrm{H}_{2} \mathrm{~S}$ at low concentrations, and it has the advantages of high $\mathrm{H}_{2} \mathrm{~S}$ removal efficiency and low cost [5]. The commonly used 
dry desulfurization methods in industrial processes are the zinc oxide method, iron oxide method, manganese desulfurization method, Claus method, etc. [6-10].

Biochar is defined as a solid, carbon-rich product obtained from biomass through various thermochemical technologies [11-14]. Pyrochar and hydrochar are two kinds of biochar prepared from the pyrolysis and hydrothermal carbonization (HTC) of biomass [15], respectively. The biomass includes straw, sawdust, the dung of herbivores, etc. [16]. Biochar is a promising alternative adsorbent for toxic gas and wastewater treatment $[17,18]$. Most researchers have focused on pyrochar, but there are a few reports on the application of hydrochar in $\mathrm{H}_{2} \mathrm{~S}$ capture. HTC is an auspicious approach for the use of waste biomass. Compared with pyrochar, hydrochar is suitable for dealing with wet biomass directly, with lower energy consumption [19-21]. Hydrochar also has higher yield and cation exchange capacity, and, during the production process, no PAHs are released. On the surface of hydrochar, it has more oxygen-containing functional groups, which is favorable for $\mathrm{H}_{2} \mathrm{~S}$ capture and oxidation $[22,23]$. Although hydrochar has such abundant advantages, it has been rarely used to treat gaseous pollutants, especially $\mathrm{H}_{2} \mathrm{~S}$.

Chitosan, insoluble in water and organic solvents, is a natural macromolecular aminopolysaccharide with a yield second only to cellulose [24]. Moreover, cornstarch is the world's largest source of starch, accounting for approximately $65 \%$ of the total amount worldwide [25]. In this work, chitosan and cornstarch were used to synthesize hydrochar, which was modified by $\mathrm{CuO}-\mathrm{ZnO}$ in a one-pot process. The aim of this work was to explore the formation of $\mathrm{CuO}-\mathrm{ZnO}$ on hydrochar, the physical and chemical properties of this new material, the desulfurization products, and the mechanisms. This work provides new insights into the development and application of hydrochar products.

\section{Results and Discussion}

\subsection{Basic Physical and Chemical Properties of Hydrochars}

The results of the EDX analyses of the hydrochars are shown in Figure 1. The mass yield (the ratio of product to the original raw biomass), ultimate analysis by $\operatorname{EDX}(\mathrm{C}, \mathrm{O}, \mathrm{N}, \mathrm{Zn}, \mathrm{Cu})$, specific surface area, pore volume, and average pore diameter are reported in Table 1. It was found that the type of precursor had a significant effect on the yield of hydrochar (Table 1). The mass yields of the solids recovered changed depending on the content and type of the precursor. With the increase in chitosan content, the yield of hydrochar and nitrogen content increased [26], because the hydrochar yield is related to the solubility of the precursors in water, and the solubility of starch is much higher than that of chitosan $[24,25]$. Simultaneously, the nitrogen in the hydrochar products mainly came from chitosan, and a small amount of nitrogen came from polyacrylamide; therefore, with the increase in the chitosan content, the nitrogen content increased.

Under the same synthetic conditions, when the ratio of chitosan to starch was 1:1, the specific surface area of hydrochar reached $30.102 \mathrm{~m}^{2} / \mathrm{g}$. It was found that, although the added amount of $\mathrm{ZnCl}_{2}$ and $\mathrm{CuCl}_{2}$ in the precursor was the same, the detected content of $\mathrm{Zn}$ in the product was much lower than that of copper. One possible reason is that the $\mathrm{pH}$ value of the filtrate during hydrothermal carbonization kept decreasing, and $\mathrm{ZnO}$ could not remain stable under the slightly acidic conditions, while $\mathrm{CuO}$ was stable under the acidic conditions.

Table 1. The yields, specific surface area, average pore diameter, and elemental composition of the synthesized hydrochars.

\begin{tabular}{cccccccccc}
\hline \multirow{2}{*}{ Hydrochar } & Yield (\%) & \multirow{2}{*}{ SSA } & PV & APD & \multicolumn{4}{c}{ Elemental Composition (\%) } \\
\cline { 7 - 9 } & & & & & C & O & Zn & Cu & N \\
\hline S5C5 & 14.83 & 30.102 & 0.071 & 8.9264 & 48.49 & 38.73 & 0.34 & 6.68 \\
S10C0 & 11.01 & 12.939 & 0.041 & 1.2464 & 36.42 & 54.34 & 0.37 & 5.57 & 0.05 \\
S3C7 & 29.89 & 16.456 & 0.069 & 1.456 & 38.85 & 42.07 & 0.36 & 6.97 & 5.93 \\
S7C3 & 14.44 & 17.244 & 0.073 & 1.6234 & 43.20 & 45.37 & 0.66 & 5.10 & 1.18 \\
S0C10 & 32.37 & 14.653 & 0.046 & 1.093 & 43.33 & 39.64 & 0.41 & 6.35 \\
S5C5N & 9.7 & 8.162 & 0.042 & 0.891 & 49.38 & 36.97 & 0.42 & 5.59 \\
\hline
\end{tabular}



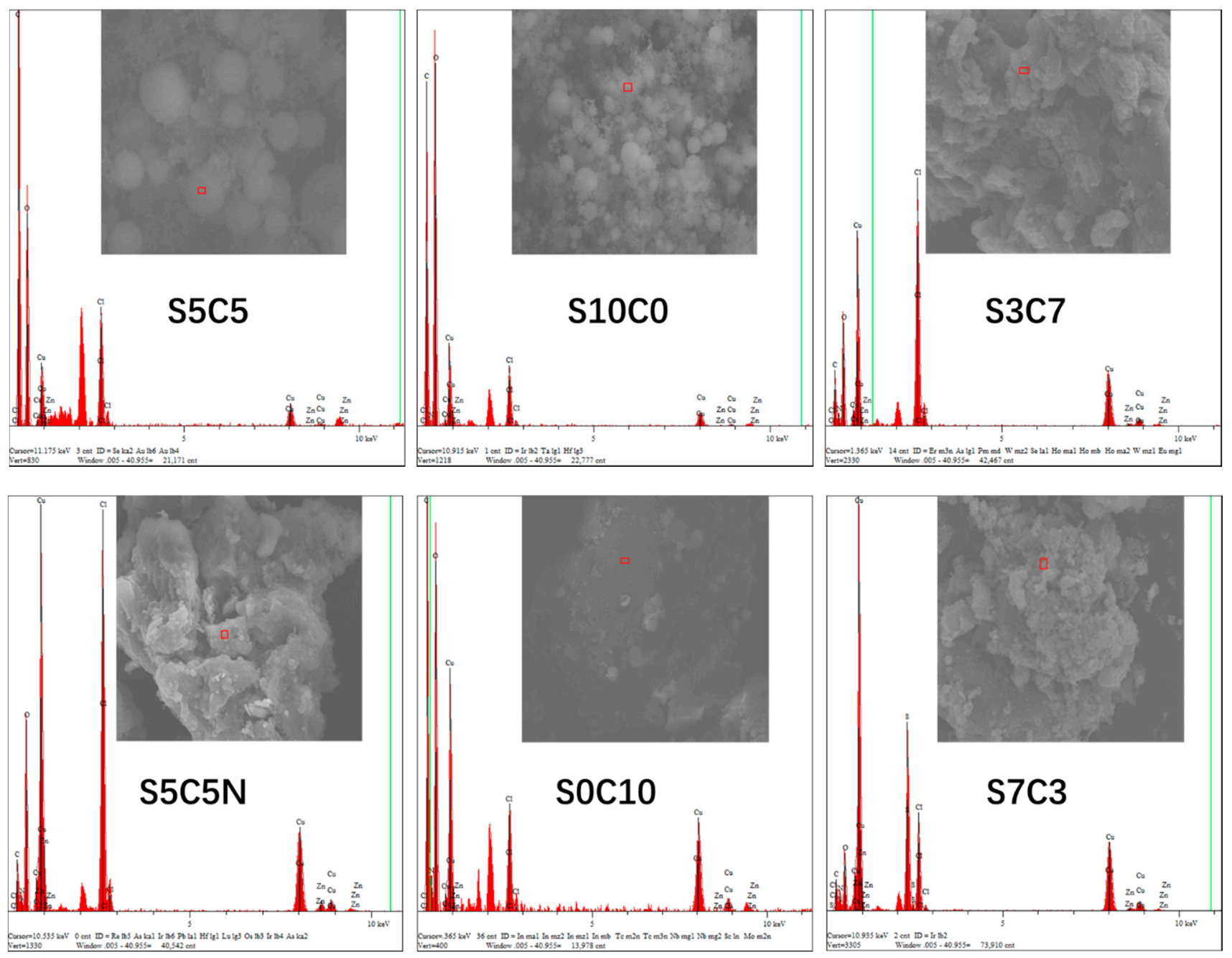

Figure 1. EDX images of the hydrochars.

FT-IR spectra of the hydrochars were used to determine the functional groups contained in the sample, and these are shown in Figure 2. The $\mathrm{C}=\mathrm{C}$ in aromatic groups showed an adsorption peak between $1613 \mathrm{~cm}^{-1}$ and $1718 \mathrm{~cm}^{-1}$. For carbonyl in $-\mathrm{COOH}$ and CO-NH, the regions from $1400 \mathrm{~cm}^{-1}$ to $1500 \mathrm{~cm}^{-1}$ were ascribed to $\mathrm{C}-\mathrm{N}$ and $\mathrm{C}-\mathrm{O}$ groups' stretching vibration. The peak at $1033 \mathrm{~cm}^{-1}$ was assigned to $\mathrm{C}-\mathrm{O}$ stretching or $\mathrm{O}-\mathrm{H}$ bending vibrations. The broad band at $3400 \mathrm{~cm}^{-1}$ can be assigned to the existence of the N-H structure. Finally, the peaks at $1033 \mathrm{~cm}^{-1}$ and $1403 \mathrm{~cm}^{-1}$ were suggested to be C-N and C-O, respectively. According to the elemental analysis and FT-IR analysis, it was proven that amine groups and oxygen-containing groups on the surface of the hydrochar were abundant.

The surface morphology of several hydrochars is shown in Figure 3. It was found that with the change in the starch and chitosan content in the precursors, the hydrochars presented different microstructures. Among all the hydrochars without polyacrylamide, the precursor starch mainly showed carbon particles and carbon spheres with diameters from $10 \mu \mathrm{m}$ to $100 \mu \mathrm{m}$, while the precursor chitosan mainly had a porous cellular structure. However, the hydrochar with polyacrylamide was dense, with no regular shape, and consisted of some carbon particles, because both chitosan and cationic polyacrylamide contained positive charges, which could make the distribution of the system more uniform. Furthermore, metal oxide clusters were not observed in any of the photomicrographs. The hydrochar samples with different starch and chitosan content were analyzed by XRD 
(in Figure 4), and this showed that the crystallinity of metal oxides in the hydrochar was low. There may be $\mathrm{ZnO}$ in $\mathrm{S} 5 \mathrm{C} 5, \mathrm{~S} 5 \mathrm{C} 5 \mathrm{~N}, \mathrm{~S} 10 \mathrm{C0}$, and free $\mathrm{Cu}$ in $\mathrm{S} 0 \mathrm{C} 10$ due to the reducibility of chitosan [27]. It indicated that the distribution of active metal sites in the hydrochar was relatively uniform or that metal oxides were embedded in carbon spheres or carbon particles [28].

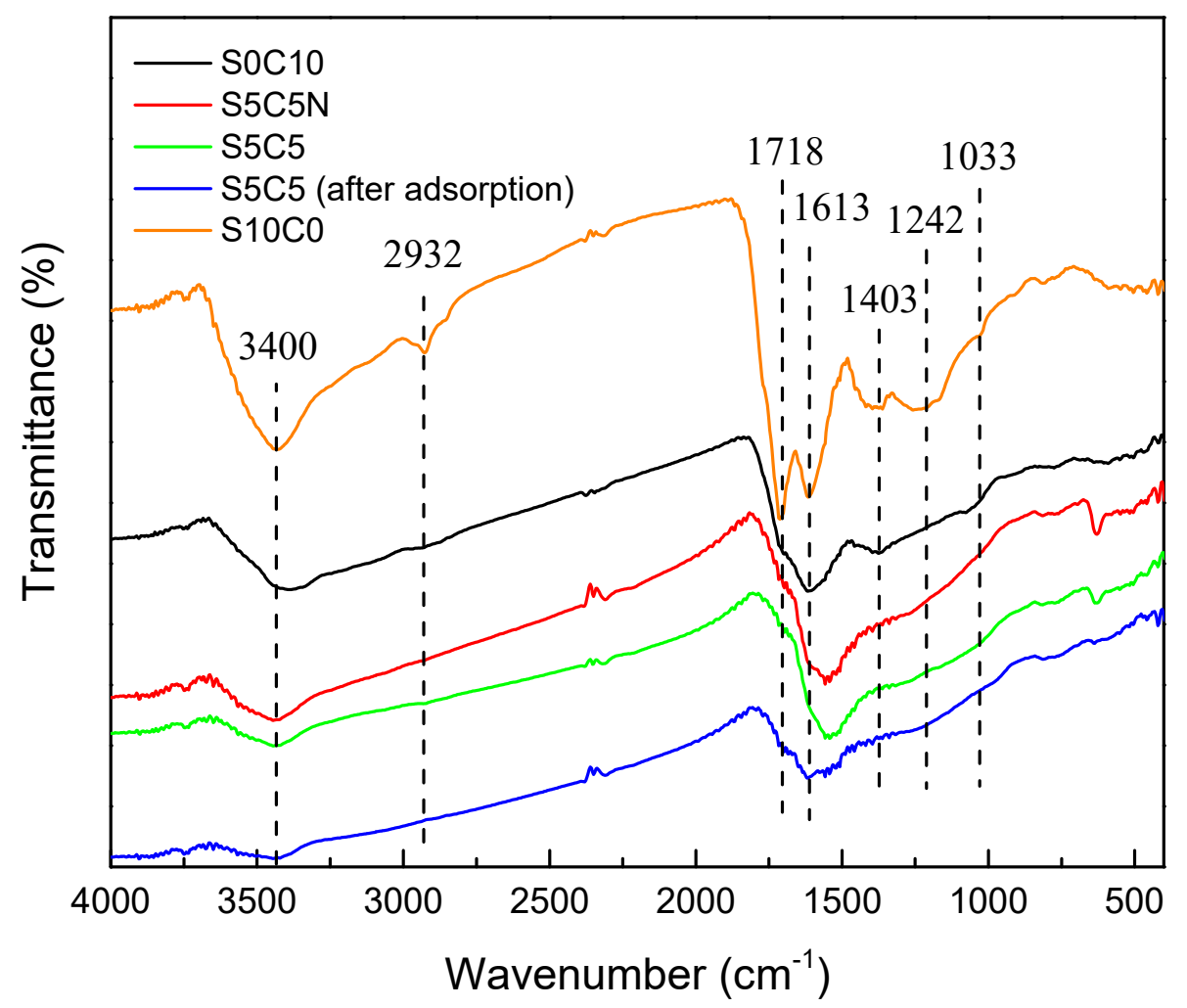

Figure 2. FT-IR spectra of the hydrochars.
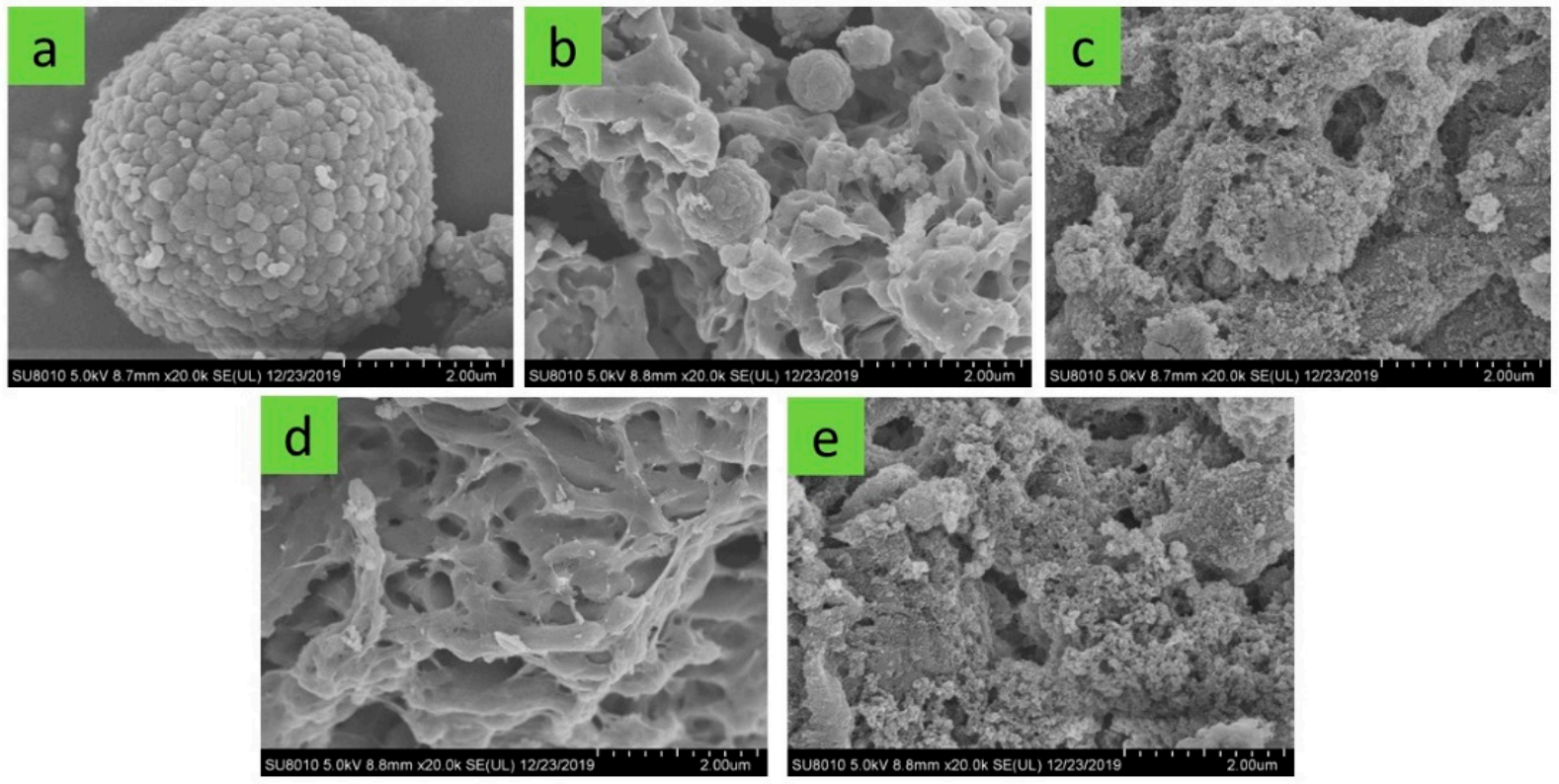

Figure 3. SEM images of different hydrochars. (a) S10C0; (b) S5C5; (c) S5C5N and (d) S0C10 before adsorption; (e) S5C5 after adsorption. 


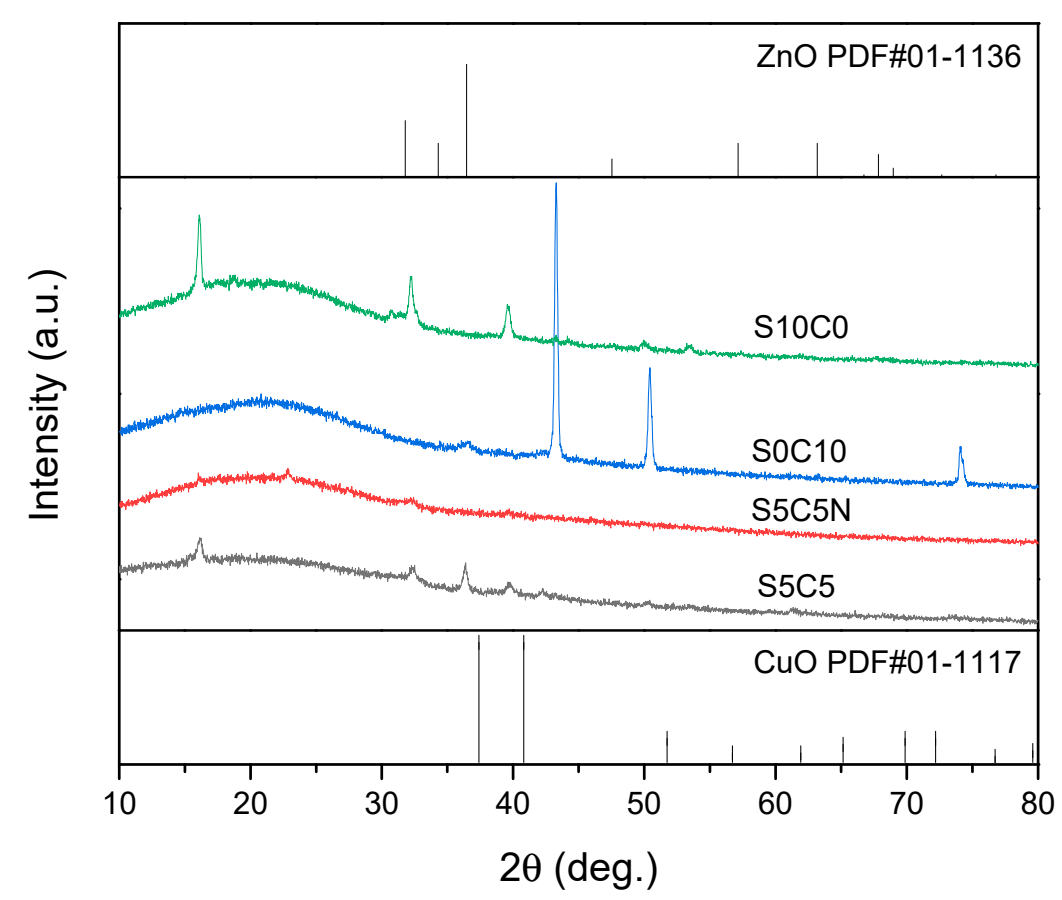

Figure 4. X-Ray diffraction patterns of hydrochar samples.

Notably, no metal oxide aggregates were observed in any of the samples. Based on previous results $[29,30]$, we believe that both the molecular weight and concentration of PAM significantly affected the morphology of the end-products. For the synthesis of nanoporous materials at a large scale, the approach was facile and had many potential applications. In addition, it was also applicative for the synthesis of other materials with a high surface area and nanoporous structures. It has been suggested that the addition of polyacrylamide can affect the morphology of the hydrochar. As an important capping agent, PAM has been widely used to synthesize materials with various nanostructures (nanorods, nanowires, nanoplates, nanocubes, etc.). The exact function of PAM on the shape selectivity is not yet fully understood; however, we believe that the selective adsorption of $\mathrm{PAM}$ on various crystallographic planes (newly formed $\mathrm{CuO}, \mathrm{ZnO}$, or hydrochar particles) suppressed their intrinsic anisotropic growth [30]. With an $\mathrm{N}-\mathrm{C}=\mathrm{O}$ group, PAM was easily attached to the surfaces of these materials and limited the growth of the crystal faces. Selective interactions between PAM and the different surface planes of the $\mathrm{CuO}$ or $\mathrm{ZnO}$ may greatly influence the growth direction and rate and ultimately result in particles with different shapes [30]. For an oxidation catalyst, its effectiveness can be mainly attributed to the adsorption and desorption of gas molecules from its surface.

\section{2. $\mathrm{H}_{2} \mathrm{~S}$ Adsorption Performance}

\subsubsection{Effect of Hydrochar Species}

In this section, a series of single-factor experiments were carried out to determine the effect of the adsorbent in the desulfurization system. The $\mathrm{H}_{2} \mathrm{~S}$ removal efficiency (\%) and breakthrough sulfur capacity were selected as the evaluation index. The ratio of chitosan to starch had a significant influence on $\mathrm{H}_{2} \mathrm{~S}$ removal. The sulfur capacities of hydrochars with different molar ratios of chitosan to starch under $180{ }^{\circ} \mathrm{C}$ were measured and are shown in Figure 5. It can be observed that the sulfur capacity of S5C5 was higher than that of other hydrochars and the addition of polyacrylamide had a great impact on $\mathrm{H}_{2} \mathrm{~S}$ adsorption. 


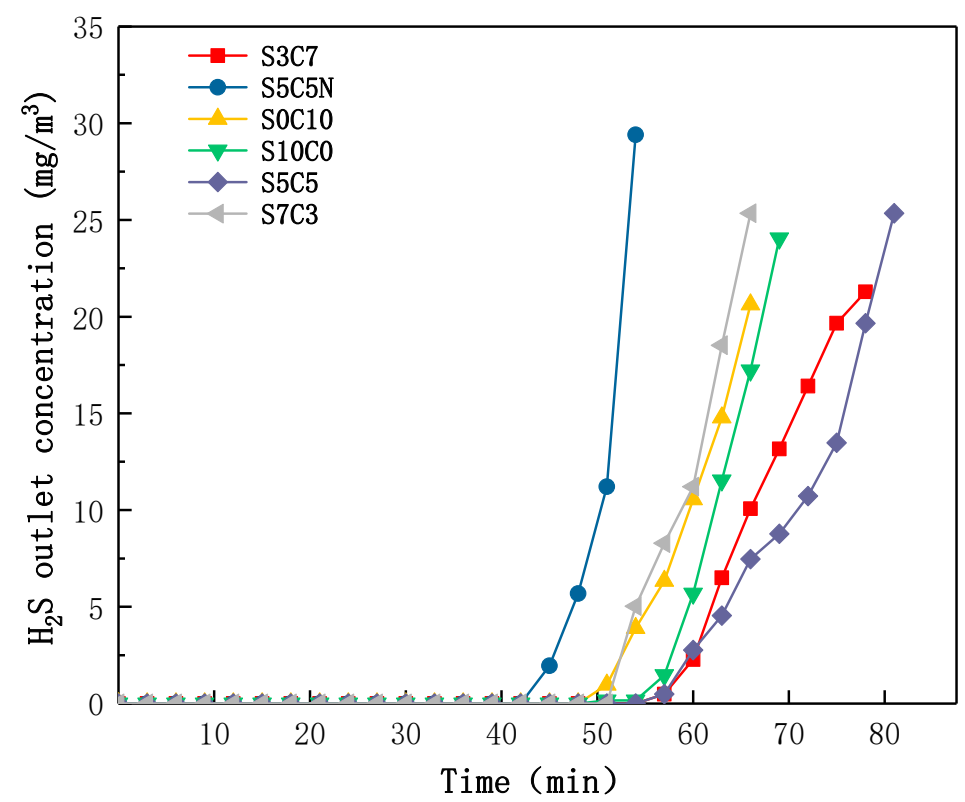

Figure 5. The breakthrough curves of hydrochar S5C5 with different molar ratios of chitosan to starch (T, $230{ }^{\circ} \mathrm{C}$; auxiliary agent, cationic PAM; cationic PAM concentration, $2.0 \mathrm{~g} / \mathrm{L}$ ).

\subsubsection{Effect of Auxiliary Agents on $\mathrm{H}_{2} \mathrm{~S}$ Removal}

Cationic PAM, polyvinylpyrrolidone, and neutral PAM were used as the auxiliary agents in the synthesis of the hydrochar. According to the experimental results, it was found that the addition of polyacrylamide and its concentration can affect the sulfur capacity. The effect of different auxiliary agents on $\mathrm{H}_{2} \mathrm{~S}$ removal by hydrochar $\mathrm{S} 5 \mathrm{C} 5$ is shown in Figure 6. Among the three auxiliary agents, the cationic PAM-synthesized hydrochar showed the best performance for $\mathrm{H}_{2} \mathrm{~S}$ removal. In order to explore the best composition of precursors, the PAM concentrations were also optimized, as shown in Figure 7. With the increasing of the PAM concentration from $0.5 \mathrm{~g} / \mathrm{L}$ to $3.0 \mathrm{~g} / \mathrm{L}$, the sulfur capacity decreased. Cationic PAM with a positive charge can attract to and interact with chitosan of a negative charge, leading to a good combination of cationic PAM in hydrochar, but the best amount of cationic PAM depended on the amount of chitosan.

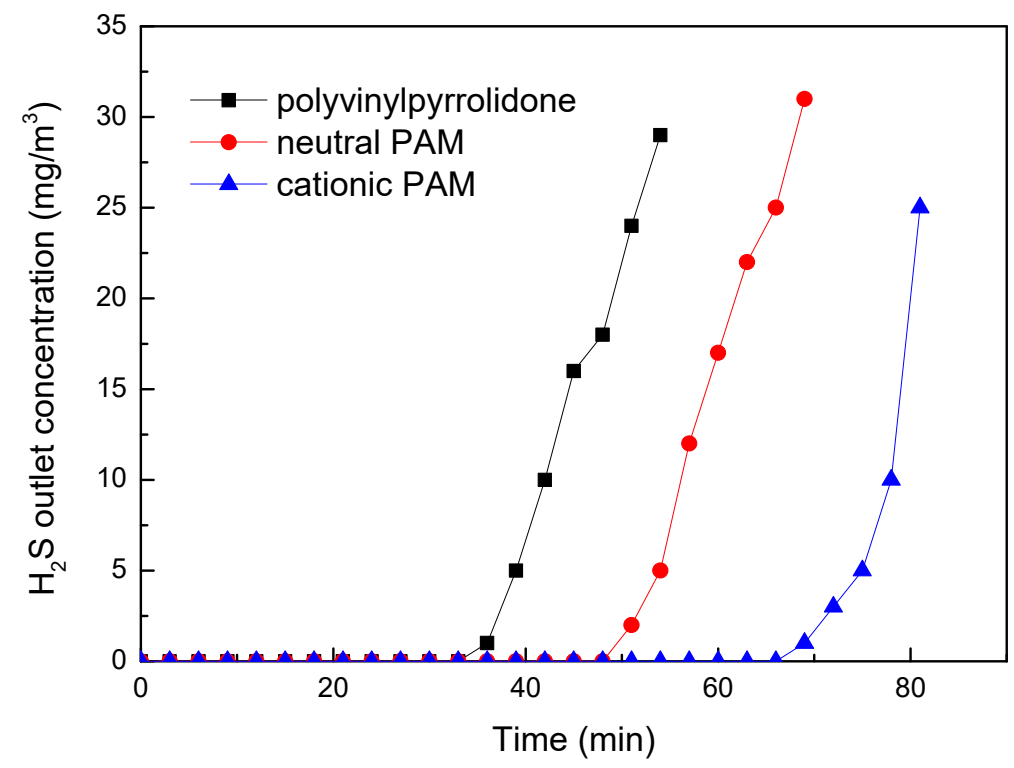

Figure 6. The breakthrough curves of hydrochar S5C5 with different auxiliary agents $\left(\mathrm{T}, 230{ }^{\circ} \mathrm{C}\right.$; auxiliary agent concentration, $2.0 \mathrm{~g} / \mathrm{L}$ ). 


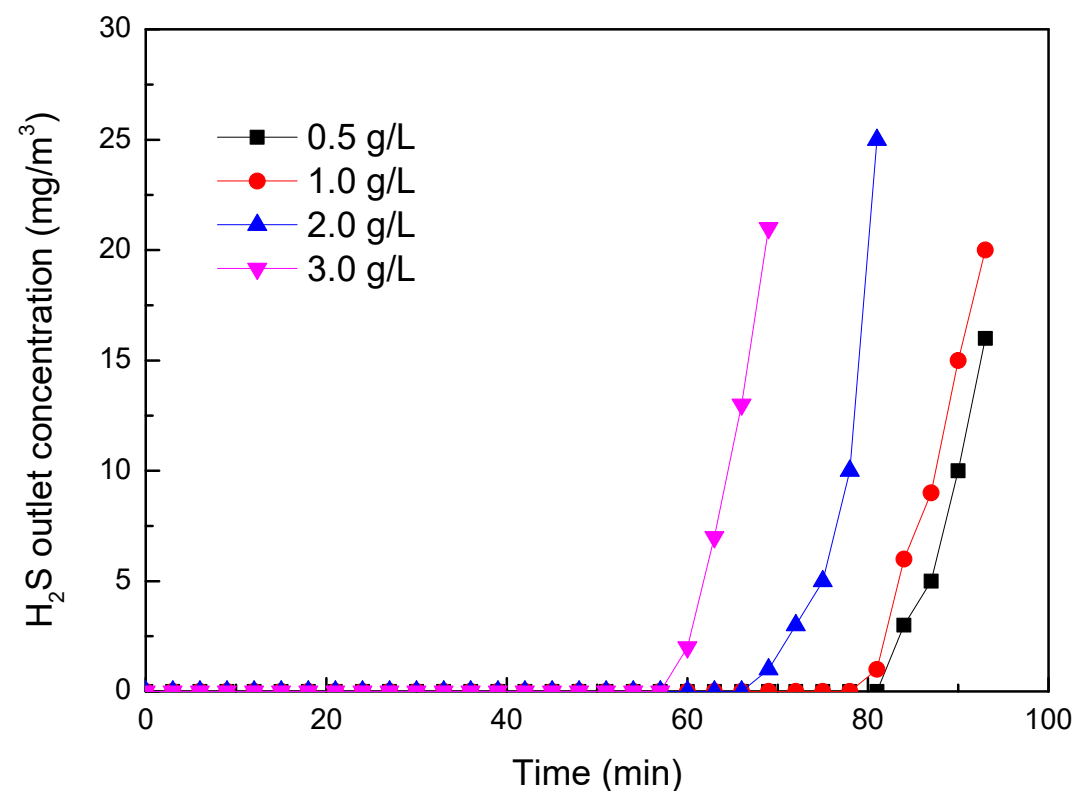

Figure 7. The breakthough curves of hydrochar S5C5 with cationic PAM of different concentrations (T, $230{ }^{\circ} \mathrm{C}$; auxiliary agent, cationic PAM).

\subsubsection{Effect of Adsorption Temperature on $\mathrm{H}_{2} \mathrm{~S}$ Removal}

The effect of adsorption temperature on $\mathrm{H}_{2} \mathrm{~S}$ removal by hydrochar $\mathrm{S} 5 \mathrm{C} 5$ is shown in Figure 8. With the desulfurization temperature increasing, the desulfurization ability of hydrochar S5C5 was clearly improved. This result indicated that the desulfurization ability of S5C5 modified by metal oxide was lower than the sorbent derived from the molecular sieve (SBA-15 or MCM-41) with modification or adsorbents with high metal content; however, it was far higher than other types of common active carbon [31-33]. As is known, a low temperature is beneficial for $\mathrm{H}_{2} \mathrm{~S}$ adsorption. Raising the temperature could enhance the molecular mobility and interaction between each reactant to promote $\mathrm{H}_{2} \mathrm{~S}$ adsorption by increasing the reaction rate; however, a higher temperature would be an obstruction to $\mathrm{H}_{2} \mathrm{~S}$ adsorption in an exothermic reaction.

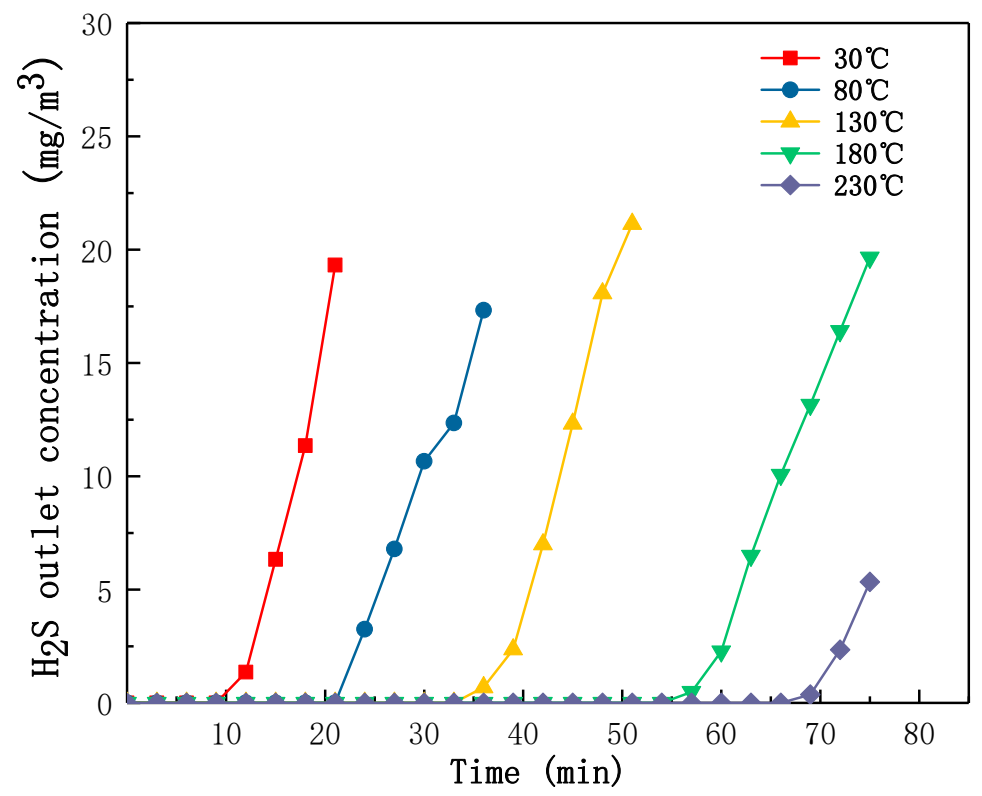

Figure 8. The breakthough curves of hydrochar S5C5 under different adsorption temperatures (auxiliary agent, cationic PAM; cationic PAM concentration, $0.5 \mathrm{~g} / \mathrm{L}$ ). 
In the adsorption and oxidation process of $\mathrm{H}_{2} \mathrm{~S}$, the change in the oxygen functional groups on the surface of the hydrochar plays an important role. The quinone and carbonyl groups on the surface of the hydrochar can react with molecular $\mathrm{H}_{2} \mathrm{~S}$. The $\mathrm{C}=\mathrm{O}$ bond and $\mathrm{C}=\mathrm{C}$ bond were broken and combined with $\mathrm{H}_{2} \mathrm{~S}$ to form the $\mathrm{S}-\mathrm{O}$ bond. This process was endothermic and favored the rising temperature. When the ratio of chitosan to starch is 1:1, the cationic PAM concentration is $0.5 \mathrm{~g} / \mathrm{L}$, and the temperature is $230{ }^{\circ} \mathrm{C}$, the maximum sulfur capacity of the hydrochar S5C5 is $28.06 \mathrm{mg} / \mathrm{g}$-adsorbent.

\subsection{Adsorption Mechanism}

The adsorption of $\mathrm{H}_{2} \mathrm{~S}$ on the hydrochar consisted of three parts: the first part is the reaction of $\mathrm{H}_{2} \mathrm{~S}$ with the metal active sites, such as $\mathrm{CuO}$ and $\mathrm{ZnO}$ [34]; the second part is the reaction of $\mathrm{H}_{2} \mathrm{~S}$ with the oxygen-containing functional groups and carbon on the surface of the hydrochar to form C-S bonds and O-S bonds; the third part is the physical adsorption process of $\mathrm{H}_{2} \mathrm{~S}$ on the surface of the hydrochar [33].

To further investigate the reaction mechanism, the chemical valence states of the element in the whole process were analyzed by XPS. The XPS spectra of $\mathrm{S}, \mathrm{Cu}$, and $\mathrm{Zn}$ are shown in Figures 9-11.

The XPS spectrum of $\mathrm{S}$ in hydrochar $\mathrm{S} 5 \mathrm{C} 5$ after $\mathrm{H}_{2} \mathrm{~S}$ adsorption is shown in Figure 9. The valence state of $S$ was confirmed within the binding energy in the range of $162-172 \mathrm{eV}$. This showed that S 2p3/2 and $\mathrm{S}^{2-} 2 \mathrm{p} 2 / 3$ appeared at $167.5 \mathrm{eV}$ and $161.7 \mathrm{eV}$, respectively. The peak at $163.4 \mathrm{eV}$ may vary due to the existence of the structure of C-S [33]. The $\mathrm{Cu}^{+}$ was confirmed by the $\mathrm{Cu} 2 \mathrm{p} 3 / 2$ binding energy in the range of $930 \mathrm{eV}$ to $937 \mathrm{eV}$, and it showed that $\mathrm{Cu}^{+} 2 \mathrm{p} 3 / 2$ appeared at $932.56 \mathrm{eV}$, and the $\mathrm{Cu}^{2+}$ was assigned to the binding energy of the XPS contribution from 928 to $937 \mathrm{eV}$ with a satellite contribution in the range of 937-947 eV, and it appeared at $934.61 \mathrm{eV}$. The $\mathrm{Zn}^{2+}$ was confirmed by the $\mathrm{Zn} 2 \mathrm{p} 3 / 2$ that appeared at $1021.77 \mathrm{eV}$. Therefore, the existing sulfur, zinc, and copper in the hydrochar S5C5 were $\mathrm{CuS}, \mathrm{ZnS}, \mathrm{Cu}_{2} \mathrm{~S}$, sulfur, and a C-S bond.

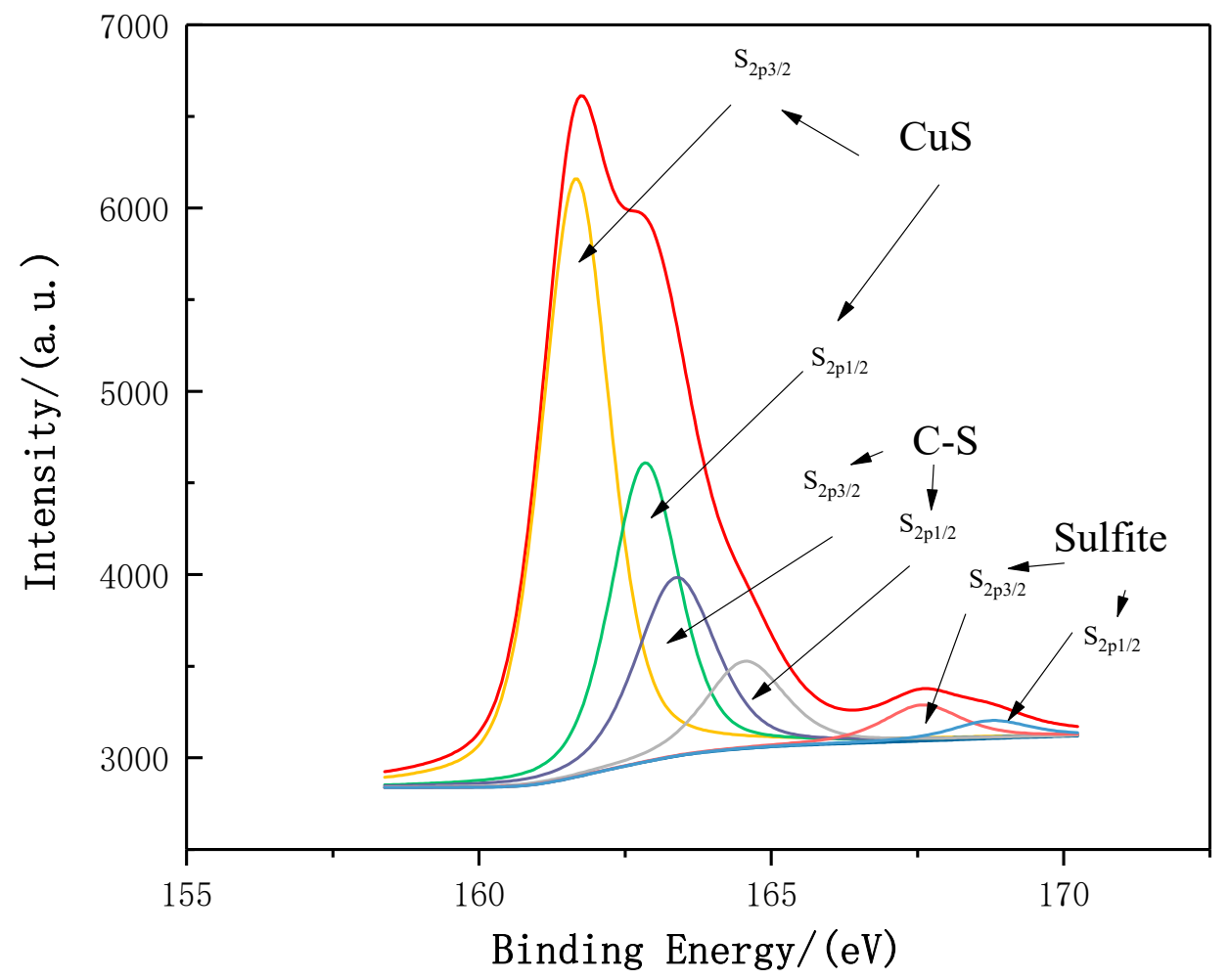

Figure 9. The XPS spectrum of $\mathrm{S}$ in hydrochar S5C5 after $\mathrm{H}_{2} \mathrm{~S}$ adsorption. 


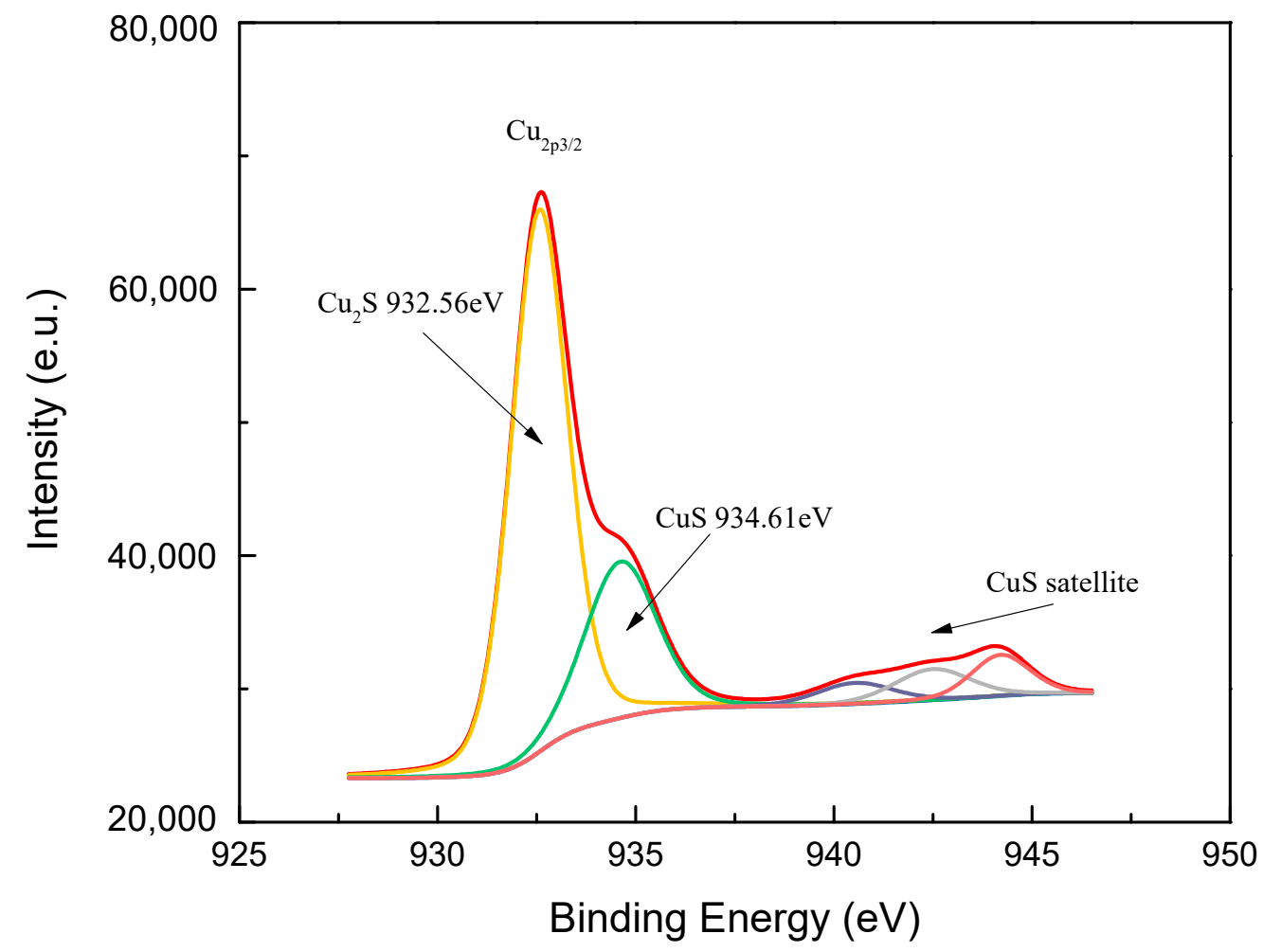

Figure 10. The XPS spectrum of $\mathrm{Cu}$ in hydrochar $\mathrm{S} 5 \mathrm{C} 5$ after $\mathrm{H}_{2} \mathrm{~S}$ adsorption.

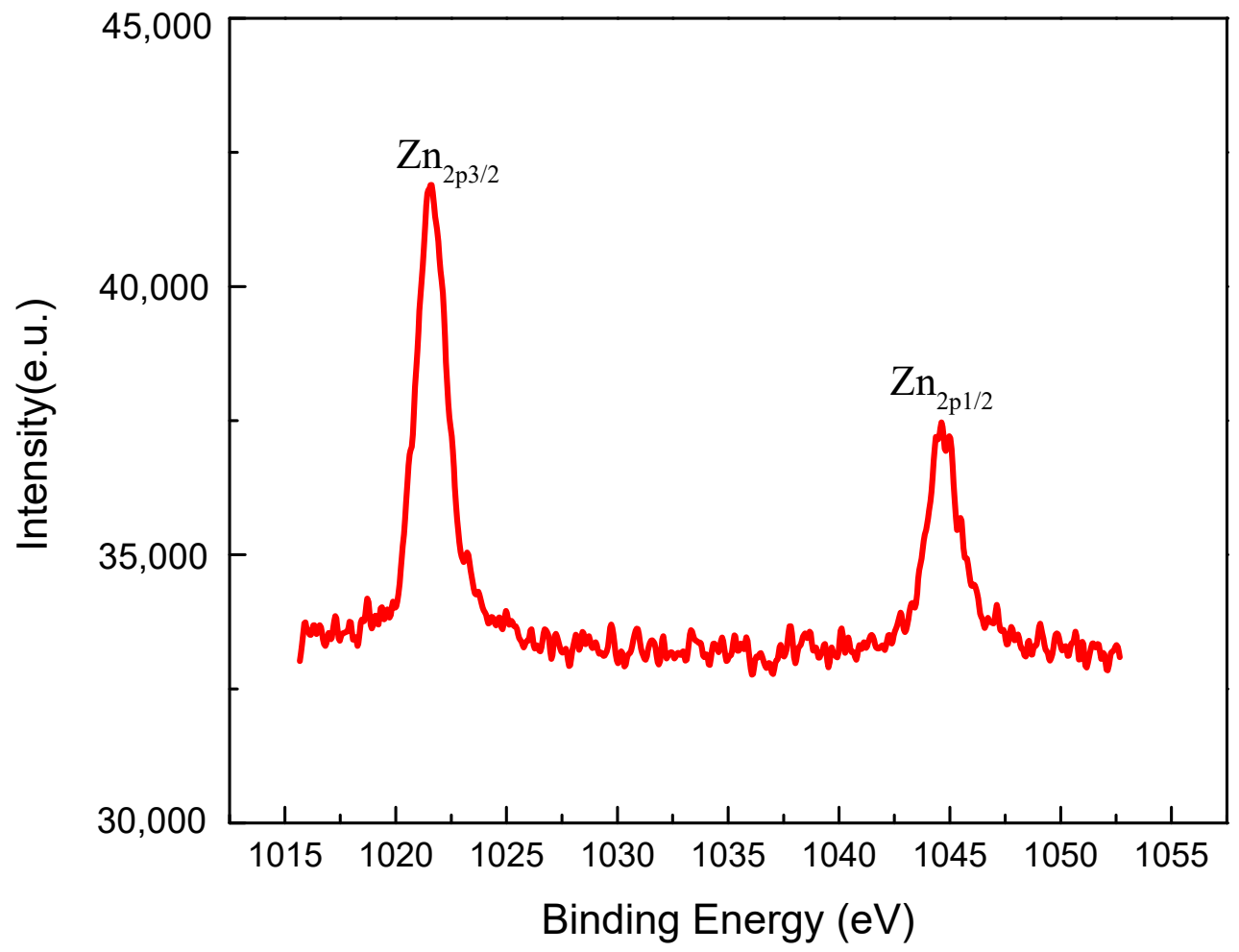

Figure 11. The XPS spectrum of $\mathrm{Zn}$ in hydrochar $\mathrm{S} 5 \mathrm{C} 5$ after $\mathrm{H}_{2} \mathrm{~S}$ adsorption.

During the hydrothermal reaction, $\mathrm{CuCl}_{2}$ and $\mathrm{ZnCl}_{2}$ reacted to form $\mathrm{CuO}$ and $\mathrm{ZnO}$. The reaction equation can be described as follows: 


$$
\begin{aligned}
\mathrm{CuCl}_{2}+\mathrm{H}_{2} \mathrm{O} & =\mathrm{Cu}(\mathrm{OH})_{2}+\mathrm{HCl} \\
\mathrm{ZnCl}_{2}+\mathrm{H}_{2} \mathrm{O} & =\mathrm{Zn}(\mathrm{OH})_{2}+\mathrm{HCl} \\
\mathrm{Cu}(\mathrm{OH})_{2} & =\mathrm{CuO}+\mathrm{H}_{2} \mathrm{O} \\
\mathrm{Zn}(\mathrm{OH})_{2} & =\mathrm{ZnO}+\mathrm{H}_{2} \mathrm{O}
\end{aligned}
$$

At the same time, copper (II) oxide has a certain oxidation capacity; $\mathrm{H}_{2} \mathrm{~S}$ can be oxidized partly to elemental sulfur and a fraction of the sulfide ions that have not been oxidized can form $\mathrm{Cu}_{2} \mathrm{~S}$ [35]. Hydrochar, rich in oxygen-containing functional groups, can combine with $\mathrm{H}_{2} \mathrm{~S}$ to form a C-S bond and $\mathrm{S}-\mathrm{O}$ bond $[33,36]$. Therefore, the form of sulfur after adsorption can be confirmed to be sulfur and a C-S bond. $\mathrm{H}_{2} \mathrm{~S}$ also can react with oxygen-containing functional groups to form sulfates in the absence of oxygen [33]. There was no oxygen gas to participate in this adsorption, so sulfate did not exist in the product.

\section{Materials and Methods}

\subsection{Materials}

The reagents, all of analytical grade, used in this experiment were purchased directly without further purification. Copper chloride, zinc chloride, cationic polyacrylamides (CPAM), and chitosan (low viscosity, deacetylation $>90 \%$ ) were purchased from Shanghai Macklin Biochemical Co., Ltd (Shanghai, China). Cornstarch (Pharmaceutical grade) was purchased from Shanghai Aladding Biochemical Technology Co., Ltd (Shanghai, China). $\mathrm{H}_{2} \mathrm{~S}$ standard gas of $1 \%$ and $\mathrm{N}_{2}$ of $99.999 \%$ were provided by Jinan Deyang Special Gas Co., Ltd (Jinan, China). The solution was prepared using laboratory-made deionized water $\left(18.3 \mathrm{M} \Omega \cdot \mathrm{cm}^{-1}\right)$.

\subsection{Preparation of Adsorbent}

There were six types of hydrochar synthesized in the experiment. All of them were composed of chitosan and cornstarch, with a cationic polyacrylamide solution (an auxiliary agent) with different dosages. The abbreviation and composition of the synthesized hydrochar samples are shown in Table 2. Taking C5S5 as an example, chitosan (3.60 g), cornstarch $(3.60 \mathrm{~g}), \mathrm{ZnCl}_{2}(0.84 \mathrm{~g})$, and $\mathrm{CuCl}_{2}(0.84 \mathrm{~g})$ were placed in a mortar, ground evenly with force, and then moved to a glass beaker, following by the addition of $45 \mathrm{~mL}$ of cationic polyacrylamide solution $(0.5,1.0,2.0$, and $3.0 \mathrm{~g} / \mathrm{L})$. While being treated with ultrasound, the precursors were stirred vigorously until a light blue color appeared. The sample was placed in a hydrothermal reactor and heated up to $230{ }^{\circ} \mathrm{C}$ for $4 \mathrm{~h}$. The product was washed repeatedly using deionized water until the $\mathrm{pH}$ of the rinsed water stabilized.

\begin{tabular}{|c|c|c|c|}
\hline Sample & Carbon Precursor (Dosage) & Auxiliary Agent & $\begin{array}{l}\text { Metal Oxide } \\
\text { Precursor } \\
\text { (Dosage) }\end{array}$ \\
\hline S5C5 & Starch (3.60 g) + Chitosan (3.60 g) & \multirow{5}{*}{$\begin{array}{l}\text { Cationic } \\
\text { polyacrylamide } \\
\text { solution }\end{array}$} & \multirow{6}{*}{$\begin{array}{c}\mathrm{ZnCl}_{2}(0.84 \mathrm{~g})+ \\
\mathrm{CuCl}_{2}(0.84 \mathrm{~g})\end{array}$} \\
\hline S10C0 & Starch (7.20 g) & & \\
\hline S3C7 & Starch $(2.16 \mathrm{~g})+$ Chitosan $(5.04 \mathrm{~g})$ & & \\
\hline S7C3 & Starch (5.04 g) + Chitosan (2.16 g) & & \\
\hline S0C10 & Chitosan (7.20 g) & & \\
\hline $\mathrm{S} 5 \mathrm{C} 5 \mathrm{~N}$ & Starch $(3.60 \mathrm{~g})+$ Chitosan $(3.60 \mathrm{~g})$ & None & \\
\hline
\end{tabular}
Other hydrochars were synthesized using the same method with different molar ratios of the precursors.

Table 2. Abbreviations and compositions of six kinds of hydrochar. 


\subsection{Characterization of Hydrochar}

The characterization of materials was investigated using a Fourier-transform infrared (FTIR) spectrophotometer (IRAffinity-1s, Shimadzu, Kyoto, Japan). X-ray diffraction (XRD) patterns of hydrochar samples were recorded on an X-ray diffractometer (SmartLab, Rigaku, Tokyo, Japan) and carried out in the $2 \theta$ range from $10^{\circ}$ to $80^{\circ}$. The surface morphologies of materials were observed by scanning electron microscope (SEM) apparatus (Regulus 8220, Hitachi, Tokyo, Japan). The element composition and valence state of materials were explored by X-ray photoelectron spectroscopy (XPS) with a multifunctional imaging electron spectrometer (ESCALAB 250XI, Thermo Fisher, Waltham, MA, America). The specific surface areas of materials were measured using the Brunauer-Emmett-Teller (BET) method, and the pore size distribution was calculated using the Barrett-Joymer-Halenda $(\mathrm{BJH})$ method from the isotherm of the adsorption branch with an automatic specific surface area and porosity analyzer (TriStar II 3020, Micromeritics, Norcross, GA, USA).

\subsection{Batch $\mathrm{H}_{2} \mathrm{~S}$ Adsorption Experiments}

The mixed gas was prepared by blending $\mathrm{H}_{2} \mathrm{~S}$ standard gas with $\mathrm{N}_{2}$, both quantified by flow indicators (D08-1F), which were purchased from Beijing Sevenstar Electronics Co., Ltd. (Beijing, China); the concentration of $\mathrm{H}_{2} \mathrm{~S}$ was measured by the gas analyzer (TH-990S) from Wuhan Tianhong Instrument Group. After adsorption, the sulfur capability was calculated by Equation (1):

$$
\mathrm{H}_{2} \text { S removal efficiency }(\%)=\frac{C_{\text {in }-} C_{\text {out }}}{C_{\text {in }}} \times 100 \%
$$

$C_{\text {in }}$ and $C_{\text {out }}\left(\mathrm{mg} \cdot \mathrm{m}^{-3}\right)$ were the inlet and outlet concentration of $\mathrm{H}_{2} \mathrm{~S}$ in the gas mixture, respectively. A diagram of the test devices for the evaluation of desulfurization performance is shown in Figure 12.

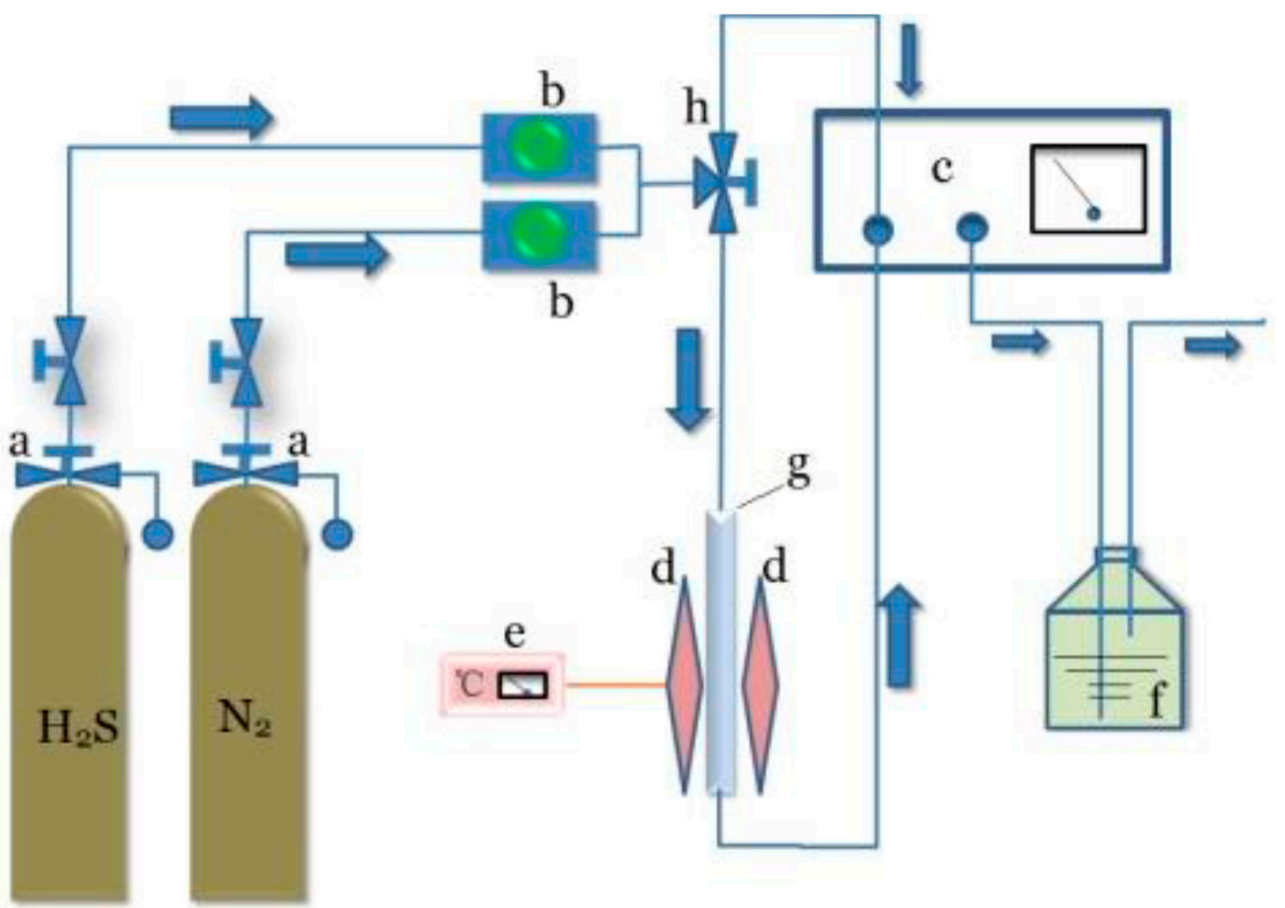

Figure 12. The diagram of test devices for the evaluation of desulfurization performance. (a) Pressure reducing valve; (b) mass flow controller; (c) portable hydrogen sulfide concentration analyzer; (d) tube furnace; (e) temperature controller; (f) concentrated lye; (g) quartz tube; (h) three-way valve.

To test sulfur capacity, a quartz tube was used and its diameter and height were $6 \mathrm{~mm}$ and $100 \mathrm{~mm}$, respectively. The adsorption temperature was controlled by a tube furnace. In the tests, a gas mixture containing $3000 \mathrm{ppm}\left(4617 \mathrm{mg} / \mathrm{m}^{3}\right)$ of $\mathrm{H}_{2} \mathrm{~S}$ (nitrogen as balance 
gas) was passed through the quartz tube filled with adsorbent of $0.5 \mathrm{~g}$, under a gas flow rate of $100 \mathrm{~mL} / \mathrm{min}$. The outlet $\mathrm{H}_{2} \mathrm{~S}$ gas was absorbed by $\mathrm{KOH}$ solution. The breakthrough sulfur capacity $\left(S_{b}, \mathrm{mg} / \mathrm{g}\right)$ was calculated in the stage from the beginning to when the $\mathrm{H}_{2} \mathrm{~S}$ outlet concentration was higher than $20 \mathrm{mg} / \mathrm{m}^{3}$ by Equation (2).

$$
S_{b}=\frac{M_{S}}{M_{H_{2} S}} \times \frac{Q_{H_{2} S}}{m}\left[\int_{0}^{t}\left(C_{\text {in }}-C_{\text {out }}\right) d t\right] \times 10^{-6}
$$

where $S_{b}$ represents the breakthrough sulfur capacity of sorbents $(\mathrm{mg} / \mathrm{g}), M_{S}$ and $M_{\mathrm{H}_{2} S}$ are the molar weight of sulfur $(32.06 \mathrm{~g} / \mathrm{mol})$ and $\mathrm{H}_{2} \mathrm{~S}(34.06 \mathrm{~g} / \mathrm{mol})$, respectively; $m$ is the weight of sorbents; $Q_{\mathrm{H}_{2} \mathrm{~S}}$ is the $\mathrm{H}_{2} \mathrm{~S}$ gas flow rate; $t$ is the reaction time for desulfurization ( $\mathrm{min}$ ), and $C_{\text {in }}$ and $C_{\text {out }}$ are the inlet and outlet concentration of $\mathrm{H}_{2} \mathrm{~S}\left(\mathrm{mg} / \mathrm{m}^{3}\right)$, respectively. When $t$ is the saturation adsorption time, Equation (2) was also used to calculate the max sulfur capacity $\left(C_{m}\right)$.

\section{Conclusions}

For $\mathrm{H}_{2} \mathrm{~S}$ adsorption, this study provides a method for the synthesis of hydrochar, obtained by the hydrothermal reaction of chitosan, starch, cationic polyacrylamide aqueous solution, $\mathrm{ZnCl}_{2}$, and $\mathrm{CuCl}_{2}$. The experimental results showed that the hydrochar contained many amino groups as functional groups, and the nano-scaled metal oxide particles had good dispersion on the surface of the hydrochar. The amine group significantly reduced the activation energy of $\mathrm{H}_{2} \mathrm{~S}$ and $\mathrm{CuO}-\mathrm{ZnO}$, which was conducive to the rapid diffusion of $\mathrm{H}_{2} \mathrm{~S}$ among the lattices. At the same time, cationic polyacrylamide as a steric stabilizer can change the formation process of $\mathrm{CuO}$ and $\mathrm{ZnO}$ nanoparticles, making the particle size smaller and allowing it to react more easily with $\mathrm{H}_{2} \mathrm{~S}$ sufficiently. When the ratio of chitosan to starch is $1: 1$, the temperature is $230{ }^{\circ} \mathrm{C}$, and the cationic PAM concentration is $0.5 \mathrm{~g} / \mathrm{L}$, the maximum sulfur capacity of the hydrochar S5C5 is $28.06 \mathrm{mg} / \mathrm{g}$-adsorbent. Therefore, modified hydrochar may be a promising adsorbent for $\mathrm{H}_{2} \mathrm{~S}$ removal.

Author Contributions: Conceptualization, Y.M. and L.Z.; methodology, J.M. and C.Z.; software, R.X.; validation, Y.M. and L.Z.; formal analysis, L.W.; resources, L.D. and L.Z.; data curation, J.M. and Y.M.; writing—original draft preparation, J.M., C.Z. and Y.M.; writing—review and editing, X.L.; funding acquisition, L.D. and L.Z. All authors have read and agreed to the published version of the manuscript.

Funding: This work was funded by the Open Research Fund Program of Key Laboratory of Cleaner Production and Integrated Resource Utilization of China National Light Industry, grant number CP-2020-YB8, Natural Science Foundation of Shandong Province, grant number ZR2020QB199, and Qilu University of Technology (Shandong Academy of Sciences) Youth Doctor Cooperation Fund, grant number 2019BSHZ0028.

Conflicts of Interest: The authors declare no conflict of interest.

\section{References}

1. Coenen, K.; Gallucci, F.; Hensen, E.; Annaland, M.V.S. Adsorption behavior and kinetics of $\mathrm{H}_{2} \mathrm{~S}$ on a potassium-promoted hydrotalcite. Int. J. Hydrog. Energy 2018, 43, 20758-20771. [CrossRef]

2. Garcia-Arriaga, V.; Alvarez-Ramirez, J.; Amaya, M.; Sosa, E. $\mathrm{H}_{2} \mathrm{~S}$ and $\mathrm{O}_{2}$ influence on the corrosion of carbon steel immersed in a solution containing 3M diethanolamine. Corros. Eng. 2010, 52, 2268-2279. [CrossRef]

3. Xiao, Y.H.; Wang, S.D.; Wu, D.Y.; Yuan, Q. Experimental and simulation study of hydrogen sulfide adsorption on impregnated activated carbon under anaerobic conditions. J. Hazard. Mater. 2008, 153, 1193-1200. [CrossRef] [PubMed]

4. Eow, J.S. Recovery of sulfur from sour acid gas: A review of the technology. Environ. Prog. Sustain. Energy 2010, 21, 143-162. [CrossRef]

5. Zhao, T.; Yao, Y.; Li, D.; Wu, F.; Zhang, C.; Gao, B. Facile low-temperature one-step synthesis of pomelo peel biochar under air atmosphere and its adsorption behaviors for $\mathrm{Ag}(\mathrm{I})$ and $\mathrm{Pb}(\mathrm{II})$. Sci. Total Environ. 2018, 640-641, 73-79. [CrossRef]

6. Zhang, X.; Dou, G.Y.; Wang, Z.; Li, L.; Wang, Y.F.; Wang, H.L.; Hao, Z.P. Selective catalytic oxidation of $\mathrm{H}_{2} \mathrm{~S}$ over iron oxide supported on alumina-intercalated Laponite clay catalysts. J. Hazard. Mater. 2013, 260, 104-111. [CrossRef] [PubMed]

7. Yasyerli, S. Cerium-manganese mixed oxides for high temperature $\mathrm{H}_{2} \mathrm{~S}$ removal and activity comparisons with V-Mn, $\mathrm{Zn}-\mathrm{Mn}$, Fe-Mn sorbents. Chem. Eng. Process. Process Intensif. 2008, 47, 577-584. [CrossRef] 
8. Khudenko, B.M.; Gitman, G.M.; Wechsler, T.E.P. Oxygen Based Claus Process for Recovery of Sulfur from $\mathrm{H}_{2} \mathrm{~S}$ Gases. J. Environ. Eng. 1993, 119, 1233-1251. [CrossRef]

9. Garces, H.F.; Galindo, H.M.; Garces, L.J.; Hunt, J.; Morey, A.; Suib, S.L. Low temperature $\mathrm{H}_{2} \mathrm{~S}$ dry-desulfurization with zinc oxide. Microporous Mesoporous Mater. 2010, 127, 190-197. [CrossRef]

10. Zhang, X.; Tang, Y.Y.; Qu, S.Q.; Da, J.W.; Hao, Z.P. H ${ }_{2}$ S-Selective Catalytic Oxidation: Catalysts and Processes. ACS Catal. 2015, 5, 1053-1067. [CrossRef]

11. Liu, Z.; Wang, Z.; Chen, H.; Cai, T.; Liu, Z. Hydrochar and pyrochar for sorption of pollutants in wastewater and exhaust gas: A critical review. Environ. Pollut. 2021, 268, 115910. [CrossRef]

12. Bridgwater, A.V.; Meier, D.; Radlein, D. An Overview of Fast Pyrolysis of Biomass. Org. Geochem. 1999, 30, 1479-1493. [CrossRef]

13. Liang, J.; Shan, G.C.; Sun, Y.F. Catalytic fast pyrolysis of lignocellulosic biomass: Critical role of zeolite catalysts. Renew. Sustain. Energy Rev. 2021, 139, 110707. [CrossRef]

14. Hardy, B.; Leifeld, J.; Knicker, H.; Dufey, J.E.; Deforce, K.; Cornélis, J.-T. Long term change in chemical properties of preindustrial charcoal particles aged in forest and agricultural temperate soil. Org. Geochem. 2017, 107, 33-45. [CrossRef]

15. Luz, F.C.; Volpe, M.; Fiori, L.; Manni, A.; Cordiner, S.; Mulone, V.; Rocco, V. Spent coffee enhanced biomethane potential via an integrated hydrothermal carbonizationanaerobic digestion process. Bioresour. Technol. 2018, 256, 102-109.

16. Liu, Y.X.; Yao, S.; Wang, Y.Y.; Lu, H.H.; Brar, S.K.; Yang, S.M. Bio- and hydrochars from rice straw and pig manure: Intercomparison. Bioresour. Technol. 2017, 235, 332-337. [CrossRef]

17. Xiao, X.; Chen, B.L.; Chen, Z.M.; Zhu, L.Z.; Schnoor, J.L. Insight into Multiple and Multi-level Structures of Biochars and Their Potential Environmental Applications: A Critical Review. Environ. Eng. Technol. 2018, 52, 5027-5047.

18. Sun, P.Z.; Li, Y.X.; Meng, T.; Zhang, R.C.; Song, M.; Ren, J. Removal of sulfonamide antibiotics and human metabolite by biochar and biochar $/ \mathrm{H}_{2} \mathrm{O}_{2}$ in synthetic urine. Water Res. 2018, 147, 91-100. [CrossRef] [PubMed]

19. Liu, Z.G.; Balasubramanian, R. Upgrading of waste biomass by hydrothermal carbonization (HTC) and low temperature pyrolysis (LTP): A comparative evaluation. Appl. Energy 2014, 114, 857-864. [CrossRef]

20. Titirici, M.M.; White, R.J.; Falco, C.; Sevilla, M. Black perspectives for a green future: Hydrothermal carbons for environment protection and energy storage. Energy Environ. Sci. 2012, 5, 6796. [CrossRef]

21. Brunner, G. Near critical and supercritical water. Part I. Hydrolytic and hydrothermal processes. J. Supercrit. Fluids 2009, 47, 373-381. [CrossRef]

22. Xia, Y.; Yang, T.X.; Zhu, N.M.; Li, D.; Chen, Z.L.; Lang, Q.Q.; Liu, Z.G.; Jiao, W.T. Enhanced adsorption of Pb(II) onto modified hydrochar: Modeling and mechanism analysis. Bioresour. Technol. 2019, 288, 121593. [CrossRef]

23. Dawood, S.; Sen, T.K.; Phan, C. Synthesis and characterization of slow pyrolysis pine cone bio-char in the removal of organic and inorganic pollutants from aqueous solution by adsorption: Kinetic, equilibrium, mechanism and thermodynamic. Bioresour. Technol. 2017, 246, 76-81. [CrossRef] [PubMed]

24. Simsir, H.; Eltugral, N.; Karagoz, S. Hydrothermal carbonization for the preparation of hydrochars from glucose, cellulose, chitin, chitosan and wood chips via low-temperature and their characterization. Bioresour. Technol. 2017, 246, 82-87. [CrossRef] [PubMed]

25. Wang, B.; Gao, W.; Kang, X.M.; Dong, Y.Q.; Liu, P.F.; Yan, S.X.; Yu, B.; Guo, L.; Cui, B.; El-Aty, A.M.A. Structural changes in corn starch granules treated at different temperatures. Food Hydrocoll. 2021, 118, 106760. [CrossRef]

26. Tekin, K.; Karagöz, S.; Bektaş, S. A review of hydrothermal biomass processing. Renew. Sustain. Energy Rev. 2014, 40, 673-687. [CrossRef]

27. Almughamisi, M.S.; Khan, Z.A.; Alshitari, W.; Elwakeel, K.Z. Recovery of chromium(VI) oxyanions from aqueous solution using $\mathrm{Cu}(\mathrm{OH})_{2}$ and $\mathrm{CuO}$ embedded chitosan adsorbents. J. Polym. Environ. 2020, 28, 47-60. [CrossRef]

28. Xu, X.W.; Huang, G.Q.; Qi, S. Properties of $\mathrm{AC}$ and $13 \mathrm{X}$ zeolite modified with $\mathrm{CuCl}_{2}$ and $\mathrm{Cu}\left(\mathrm{NO}_{3}\right)_{2}$ in phosphine removal and the adsorptive mechanisms. Chem. Eng. J. 2017, 316, 563-572. [CrossRef]

29. Peng, Y.; Liu, Z.Y.; Yang, Z.H. Polymer-Controlled Growth of CuO Nanodiscs in the Mild Aqueous Solution. Chin. J. Chem. 2009, 27, 1086-1092. [CrossRef]

30. Zhou, M.; Gao, Y.; Wang, B.; Rozynek, Z.; Fossum, J.O. Carbonate-Assisted Hydrothermal Synthesis of Nanoporous CuO Microstructures and Their Application in Catalysis. Eur. J. Inorg. Chem. 2010, 5, 729-734. [CrossRef]

31. Mureddu, M.; Ferino, I.; Rombi, E.; Cutrufello, M.G.; Deiana, P.; Ardu, A.; Musinu, A.; Piccaluga, G.; Cannas, C. ZnO/SBA-15 composites for mid-temperature removal of $\mathrm{H}_{2} \mathrm{~S}$ : Synthesis, performance and regeneration studies. Fuel 2012, 102, 691-700. [CrossRef]

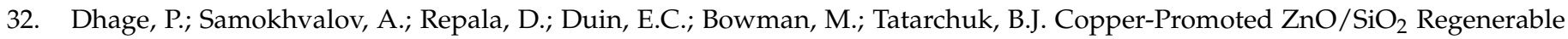
Sorbents for the Room Temperature Removal of $\mathrm{H}_{2} \mathrm{~S}$ from Reformate Gas Streams. Ind. Eng. Chem. Res. 2010, 49, 8388-8396. [CrossRef]

33. Li, Y.R.; Lin, Y.T.; Xu, Z.C.; Wang, B.; Zhu, T.Y. Oxidation mechanisms of $\mathrm{H}_{2} \mathrm{~S}$ by oxygen and oxygen-containing functional groups on activated carbon. Fuel Process. Technol. 2019, 189, 110-119. [CrossRef] 
34. Falco, D.G.; Montagnaro, F.; Balsamo, M.; Erto, A.; Deorsola, F.A.; Lisi, L.; Cimino, S. Synergic effect of Zn and Cu oxides dispersed on activated carbon during reactive adsorption of $\mathrm{H}_{2} \mathrm{~S}$ at room temperature. Microporous Mesoporous Mater. 2018, 257, 135-146. [CrossRef]

35. Kim, S.-J.; Na, C.W.; Hwang, I.-S.; Lee, J.-H. One-pot hydrothermal synthesis of CuO-ZnO composite hollow spheres for selective $\mathrm{H}_{2} \mathrm{~S}$ detection. Sens. Actuators B Chem. 2012, 168, 83-89. [CrossRef]

36. Boutillara, Y.; Tombeur, J.L.; De Weireld, G.; Lodewyckx, P. In-situ copper impregnation by chemical activation with $\mathrm{CuCl}_{2}$ and its application to $\mathrm{SO}_{2}$ and $\mathrm{H}_{2} \mathrm{~S}$ capture by activated carbons. Chem. Eng. J. 2019, 372, 631-637. [CrossRef] 